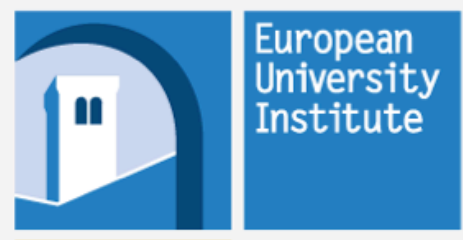

Middle

East

Directions

\section{The Developmental State} Experience in Ethiopia and Rwanda: Lessons for Libya?

Mehari Taddele Maru 
(C) European University Institute 2021

Content and individual chapters (C) Mehari Taddele Maru, 2021

This work has been published by the European University Institute,

Robert Schuman Centre for Advanced Studies.

This text may be downloaded only for personal research purposes. Additional reproduction for other purposes, whether in hard copies or electronically, requires the consent of the authors. If cited or quoted, reference should be made to the full name of the author(s), editor(s), the title, the year and the publisher.

Requests should be addressed to med@eui.eu.

Views expressed in this publication reflect the opinion of individual authors and not those of the European University Institute.

Middle East Directions

Robert Schuman Centre for Advanced Studies

Research Project Report

RSCAS/Middle East Directions 2021/06

May 2021

European University Institute

Badia Fiesolana

I - 50014 San Domenico di Fiesole (FI)

www.eui.eu/RSCAS/Publications/

cadmus.eui.eu 


\title{
The Developmental State Experience in Ethiopia and Rwanda: Lessons for Libya? ${ }^{1}$
}

\author{
Mehari Taddele Maru
}

1 This research paper is part of a series of publications prepared in the framework of the 'Dialogue Platform for Peace and Stability in Libya.' The project aims to establish a platform for dialogue and exchange between Libya's major political forces, Libyan and international researchers and key actors in the international community on key policy issues for Libya's future.

2 Mehari Taddele Maru is a part-time Professor, Migration Policy Centre and Academic Coordinator, Young African Leaders Programme, School of Transnational Governance, European University Institute; @DrMehari. The author thanks colleagues at the Middle East Directions Programme, particularly Luigi Narbone, Virginie Collombier, and May Tamimova, for their comments and help in this research. The author takes sole responsibility for any errors. 


\section{Table of Contents}

$\begin{array}{lr}\text { Executive Summary } & 1\end{array}$

Introduction: a Libyan State Model and an Economic Vision 2

Part One: Key Elements of the Developmental State Model 3

The Tenets of the Developmental State 3

Delivery and Stability First, Democracy Follows $\quad 4$

The Transition to a Post-Conflict Economy and Development 5

Part Two: The Ethiopian and Rwandan Developmental States: Experiences and $\begin{array}{ll}\text { Shortcomings } & 6\end{array}$

$\begin{array}{ll}\text { Ethiopia } & \mathbf{6}\end{array}$

Socio-Economic Progress and Improvement in Education $\quad 6$

\begin{tabular}{l} 
Political Life \\
\hline
\end{tabular}

$\begin{array}{ll}\text { From Success to Civil War } & 8\end{array}$

$\begin{array}{lr}\text { Rwanda } & 10\end{array}$

$\begin{array}{lr}\text { Economic and Political Achievements } & 10\end{array}$

A Developmental State from the Ashes of Genocide 11

Shortcomings of the developmental state model in the cases of Ethiopia and Rwanda 12

$\begin{array}{ll}\text { Part Three: Lessons for Libya } & 13\end{array}$

Possible Interpretations of the Developmental State Model in Libya $\quad 13$

A Post-Conflict Reconstruction and Development (PCRD) Plan 13

$\begin{array}{ll}\text { State Security and Defence } & 14\end{array}$

$\begin{array}{lr}\text { Decentralised Governance } & 15\end{array}$

$\begin{array}{ll}\text { Resource Governance } & 15\end{array}$

Conclusions: Key Requirements for a Developmental State Model in Libya $\quad 16$

$\begin{array}{ll}\text { Political Legitimacy and Political Continuity } & 17\end{array}$

$\begin{array}{ll}\text { Agreement on Political and Economic Vision } & 18\end{array}$

$\begin{array}{lr}\text { References } & 19\end{array}$ 


\section{Executive Summary}

Libya's present complicated transitional situation offers an opportunity to discuss a new state model which is less path-dependent and more reflective of the country's long-term peace and development needs. Libyans have an opportunity to choose between the liberal market-led model, the developmental state model or the welfare state model as an in-between. They may also choose to blend and harmonise elements from different models that they find most suitable to the particularity of the Libyan context.

Among these options, what would be the advantages and disadvantages of the developmental state model in addressing the challenges Libya is currently facing? What lessons can Libya learn from the experience of developmental states, particularly countries such as Rwanda and Ethiopia? Although they are different in many ways, these two countries have gone through post-war/post-genocide stabilisation and reconstruction processes, and by applying the developmental state model have achieved fast economic growth.

Building upon the developmental state trajectories in the cases of pre-2018 Ethiopia and Rwanda, the paper argues that, if Libya is to enjoy peace, prosperity and democracy, it can benefit from more, not less, state intervention.

Establishing an efficient and effective state would one of the vital tasks in Libya's transition. It could significantly contribute to rapid peacebuilding and development. The peacebuilding and state-building process would require a normative framework and a high state capability to restore law and order, stability and effective socio-economic institutions that can allocate public resources, make and enforce laws and adjudicate disputes.

In Libya, the developmental state model may take the form of post-conflict reconstruction and development plans with the aim of stabilisation, state building, and democratisation. In the current context, developmental state would relate to the sequence of actions that would place appropriate stress on security, resource governance, development, and democracy. However, in order to achieve these objectives, key requirements would need to be met, including political agreement on the development model and political legitimacy of its implementors. 


\section{Introduction: a Libyan State Model and an Economic Vision}

The new Libyan Government of National Unity (GNU) headed by Abdel-Hamid Dbaiba was sworn into office on 15 March 2021. ${ }^{3}$ It will face the same challenges that characterised the previous transitional authorities: ${ }^{4}$ ending the civil war, bringing peace, sustainable stability, inclusive governance and democracy; ${ }^{5}$ maintaining the country's unity and autonomy from external interference; ${ }^{6}$ addressing the war economy ${ }^{7}$ and financial crisis; ${ }^{8}$ and fostering fast and fair economic development for all citizens. ${ }^{9}$

After almost a decade of statelessness and civil war, the selection and adoption of a model for the state is a critical undertaking. What state model may help guide the country to having a stable political economy and inclusive constitutional design that can address the above and other challenges? What kind of state system would ensure peace, stability, democracy, development and unity in Libya?

Libya has an opportunity to choose between a liberal market-led model, a developmental state model or a welfare state model as an in-between. ${ }^{10}$ Scandinavian countries are good examples of the social welfare state model. However, such states begin as developmental states with heavy resource allocation to social welfare. ${ }^{11}$ The current realities on the ground in Libya are unfavourable for a liberal or social welfare state model since there is no monopoly of violence in the central government's hands. It also lacks the strong regulatory and enforcement institutions that are essential for an effective liberal state. ${ }^{12}$ Furthermore, a neoliberal state has a lower capacity to promote social cohesion and allocate national resources in such a way as to build the state's capacity to overcome adversity. For instance, the Covid-19 pandemic has shown that, compared to the South Korean developmental state, the neoliberal model of the state does not serve society well in a time of distress, as Libya finds itself in.

\footnotetext{
3 “'One and united:' Libya interim government sworn in,” Aljazeera, 15 March 2021: https://www.egypttoday.com/ Article/1/99718/Libya-s-new-interim-government-takes-oath-of-office-before

4 Eljarh, Mohamed, “Analysis: Libyan Political Dialogue Forum Appoints New Government for Libya," Libya Desk, 7 February 2021: https://www.libyadesk.com/articles/libya-new-government-analysis?format=amp\& twitter impression=true
}

5 Wehrey, Frederic, "This War is Out of Your Hands," Centre on the Future of War, 14 September 2021: https://www. newamerica.org/international-security/reports/this-war-is-out-of-our-hands/; Maru, Mehari Taddele, "Why the US is engineering political change in East Africa," Aljazeera, 9 October 2018: https://www.aljazeera.com/opinions/2018/10/9/ why-the-us-is-engineering-political-change-in-east-africa

6 “Libya Economic Monitor,” World Bank Group, 14 August 2020: https://www.worldbank.org/en/region/mena/ publication/libya-economic-monitor

7 Eaton, Tim, "Libya's War Economy: Predation, Profiteering and State Weakness," Chatham House: The Royal Institute of International Affairs, 12 April 2018: https://www.chathamhouse.org/2018/04/libyas-war-economy-predationprofiteering-and-state-weakness

8 "Of Tanks and Banks: Stopping a Dangerous Escalation in Libya," International Crisis Group Middle East and North Africa Report, 20 May 2019: https://www.crisisgroup.org/middle-east-north-africa/north-africa/libya/201-tanks-andbanks-stopping-dangerous-escalation-libya

9 Ibid; Wehrey, Frederic, op. cit.; "Libya Economic Monitor," op. cit.; Eaton, Tim, op. cit.; “Inside Libya," Konrad Adenauer Stiftung, February 2021: https://www.kas.de/documents/282499/282548/INSIDE+LIBYA+January+Editi. $\mathrm{pdf} / 8 \mathrm{c} 9 \mathrm{cab} 27-2628-2 \mathrm{fb} 6-5703-647 \mathrm{~d} 5 \mathrm{a} 5 \mathrm{c} 66 \mathrm{df}$ ?version=1.0\&t=1612256132148

10 Bresser-Pereira, Luiz Carlos, “Models of the developmental state," CEPAL Review, August 2019: https://www.cepal.org/ en/publications/44978-models-developmental-state

11 Ibid.

12 Onis, Ziya, “Review: The Logic of the Developmental State.” Comparative Politics, Vol.24, Issue 1, 1991. 
In this regard, Libya may learn from the post-war experiences of two African developmental states, namely pre-2018 Ethiopia ${ }^{13}$ and Rwanda. ${ }^{14}$ Although they are different in many ways, these two countries were selected for two main reasons. Both have gone through post-war/post-genocide stabilisation and reconstruction processes and by applying the developmental state model have achieved fast economic growth. In their own distinct approaches, they have tried to address what they consider the root causes of their protracted civil wars: extreme poverty and a lack of accommodation of diversity.

Rwanda successfully emerged after the 1994 genocide, as did Ethiopia after three decades of protracted civil war. However, there are stark dissimilarities among the three countries. For instance, Libya has one of the largest proven oil reserves, which Rwanda and Ethiopia lack. While Libya has a much smaller population (half that of Rwanda and a sixteenth that of Ethiopia), Rwanda and Ethiopia are more ethnically and religiously heterogeneous. Although Libya might be ethnically less heterogeneous than Ethiopia and Rwanda, accommodation of diversity based on regional and identity diversity remain central in any the Libyan post-conflict governance. Thus, some lessons can be drawn from their experiences.

Against the background of these two cases, this paper discusses two interlinked critical questions. First, what elements of the developmental state are relevant to Libya and its political, economic and cultural affairs? And second, given the differences between the positions of Libya's domestic and external forces, is it even possible to establish a developmental state there?

In Part One it discusses the core tenets of the developmental state and the phases in its implementation. Part Two discusses the cases of the Rwandan and Ethiopian developmental states as examples that have achieved fast economic growth after periods of protracted conflict and a lack of diversity governance. ${ }^{15}$ Part Three discusses how these examples may help inform discussions on Libya's post-conflict economic model, by analysing the opportunities and challenges presented by the developmental state model in the Libyan context. The paper ends with recommendations for a way forward, without prescribing a specific model as the only one available for Libya.

\section{Part One: Key Elements of the Developmental State Model}

\section{The Tenets of the Developmental State}

In contrast with the liberal state, and as an alternative to it, the developmental state "is a state where the government is intimately involved in the macro and microeconomic planning to grow the economy," "while attempting to deploy its resources in developing better lives for the people." ${ }^{16}$ According to Oxford Reference, the developmental state is "a form of government involving direct, concerted, and sustained intervention in national economic development through industrial policies such as exportled growth and labour control." In the early 1980s, in an attempt to understand its extraordinary economic development, Chalmers Johnson (1982), called Japan a "developmental state." The term

\footnotetext{
13 For details, see Maru, Mehari Taddele, "The old EPRDF is dead, can its system be saved? Five steps to save the federation," Ethiopia Insight, 3 October 2018: https:/www.ethiopia-insight.com/2018/10/03/the-old-eprdf-is-dead-canits-system-be-saved-five-steps-to-save-the-federation/

14 For details, see Maru, Mehari Taddele, "Rwanda and President Kagame," Aljazeera Centre for Studies, 9 September 2017: https://studies.aljazeera.net/en/reports/2017/09/rwanda-president-kagame-170909121048238.html

15 The two cases were selected based on the interest of Libyan scholars and politicians in learning more about the developmental state in Ethiopia and Rwanda.

16 “Developmental State Model," UN Economic and Social Commission for Western Asia, 9 November 2017: https:// www.unescwa.org/developmental-state-model
} 
is generally applied to east Asian countries like Japan, South Korea and Taiwan, where in the late $20^{\text {th }}$ century technocrats and planners were responsible for strategically shaping the economies rather than just indirectly regulating them. ${ }^{17}$ In this regard, in 1962, Hélio Jaguaribe argued that "the core thesis of developmentalism is that the promotion of economic development and the consolidation of nationality stand as two correlated aspects of a single emancipatory process." ${ }^{18}$ Developmental states "combined state intervention with a dynamic private sector, modelling themselves on Japan." 19

A developmental state's political economy "is based on the concepts of the developmental state and developmental capitalism." ${ }^{20}$ In other words, in a developmental state there is a blend of structuralist development theory and Keynesian macroeconomics with public-expenditure-driven economic development. The focus is on transformation through massive expansion and scaling-up programmes in education, health, infrastructure and social governance. As an applied political-economic governance model and with consolidation of the monopoly of violence, the major preoccupation of the developmental state is economic growth with a strong pro-poor policy. In a developmental state, the country's economic development dictates the overall function of the state and the allocation of resources.

Accordingly, the developmental state monopolises the means and use of violence, norm-setting mandates, regulatory and enforcement powers and economic space. Its legitimacy stems from its performance in achieving high-quality and -quantity standards in the delivery of public goods. The developmental state allocates resources to public expenditure without facing the checks that a liberal state with market-led resource allocation would otherwise face. This limitation of constraints on the state allows autonomy in policymaking (both at the domestic and external levels) and accelerates fair economic development and state-building. ${ }^{21}$ Consequently, prime national resources such as oil and gas can be owned and mobilised by the state for effective governance, pro-poor public social services, industrialisation, post-war reconstruction and development.

In cases of successful transformation, the developmental state requires both a long-term vision and a recognition of the state's irreplaceable role in socio-political and economic transformation.

\section{Delivery and Stability First, Democracy Follows}

Expressed briefly, the developmental state relies heavily on fast and effective delivery of services to improve citizens' wellbeing. If a developmental state fails to meet this objective, it loses its legitimacy. Generally, but not exhaustively, democracy in Africa can be equated with uncertainty, instability and inefficacy, while the developmental state is a sine qua non for stability and delivery. Democracy is relegated to a secondary order of importance and often even lower than that. While short on popular legitimacy, the developmental state relies on its delivery capability to recoup political kudos. Nevertheless, the delivery of social goods can help bring about social stability and potentially improve the democratic propensity of the population. Impressive economic performance cannot, however, substitute for constitutional democracy. ${ }^{22}$ Effectiveness in delivery and maintaining stability is a source of legitimacy for authority, but only democracy ensures the sustainability of that legitimacy.

17 Rodgers, Alisdair, Noel Castree and Rob Kitchin. n.d., "A dictionary of Human Geography: Developmental State," Oxford Reference, 2013: https://www.oxfordreference.com/view/10.1093/acref/9780199599868.001.0001/acref9780199599868-e-391

18 Bresser-Pereira, Luiz Carlos, op. cit.

19 Ibid.

20 Ibid.

21 Ibid.

22 Sen, Armatya. Development as Freedom, New York: Anchor Books, 1991. 
Development and freedom are strongly related. When poverty is rampant, freedom remains in danger, and without freedom poverty eradication will be all but impossible. ${ }^{23}$ When delivery and stability are pursued at the expense of democracy, a country's polity may be lost.

\section{The Transition to a Post-Conflict Economy and Development}

A transition to a post-conflict society is too important to be left to the free market alone. An economic crisis has potential implications for peace and security in a country. ${ }^{24}$

The developmental state not only provides the legislative, regulatory and enforcement mechanisms within which the market operates but also determines the end state and defines the direction of the political economy. The private sector operates within limits laid down by the state, while the state runs the economy and finances the public sector. As a result, the developmental state encroaches on the realm of the private sector in many areas of public interest to correct current and future financial and economic crises. ${ }^{25}$ In both theory and practice, it is the public sector that dominates the economic space. While doing this, it leads all interests, including public and private actors engaged in economic activities.

Accordingly, in addition to controlling the economy, the state monopolises the means and use of violence, norm-setting mandates and regulation and enforcement powers. In this way it reverses the conventional capitalist conception of the roles of public and private sectors. In a market economy, the state intervenes to correct market adjustments and failures. In contrast, in a developmental economy the government acts as the prime investment agency and the private sector intervenes to complement the public investment and economic action. In a nutshell, the private sector fills the 'gaps' in the economy left by the state. While the state dominates the economy, the private sector plays a supporting role. In a transitional process, the developmental state offers a better opportunity to achieve successful transitional state-building, national policy sovereignty and economic catch-up after a destructive war. ${ }^{26}$

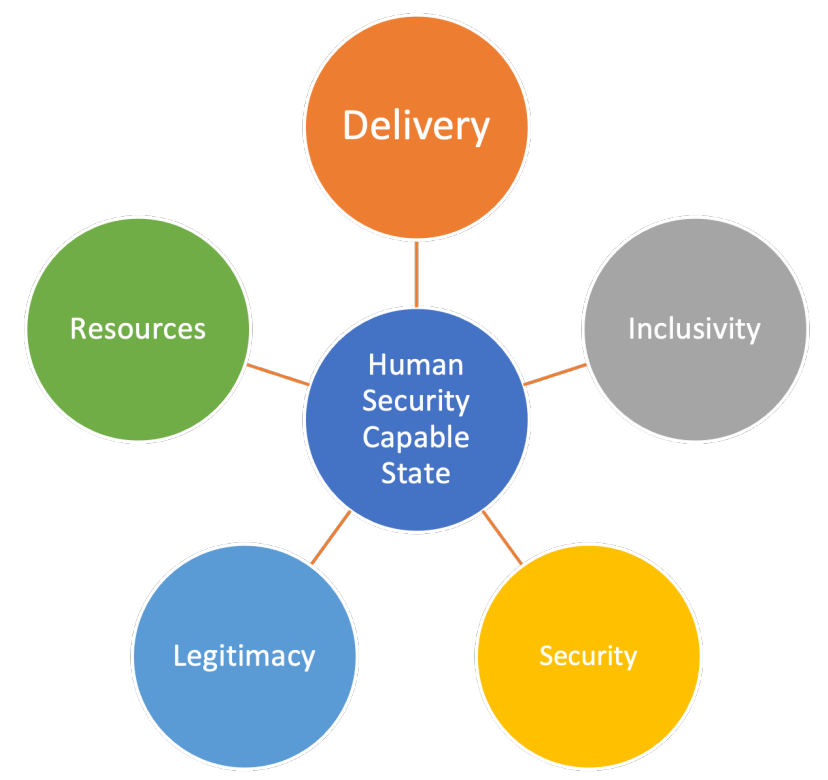

Key Components of the Developmental State (Mehari Maru, 2014)

23 Gay, John, "Development as Freedom: a virtuous circle?” Afrobarometer, 2003: https://afrobarometer.org/ publications/wp29-development-freedom-virtuous-circle

24 “Libya Economic Monitor,” op. cit.; "Of Tanks and Banks: Stopping a Dangerous Escalation in Libya,” op. cit.

25 Ibid.

26 Bresser-Pereira, Luiz Carlos, op. cit. 


\section{Part Two: The Ethiopian and Rwandan Developmental States: Experiences and Shortcomings}

\section{Ethiopia}

Socio-Economic Progress ${ }^{27}$ and Improvement in Education

With a population of more than 112.1 million, ${ }^{28}$ Ethiopia is the second-most populous country in Africa. $35.7 \%$ of the population are below the age of $14 .{ }^{29}$ With an average fertility rate of 3.4 children per woman and $2 \%$ average annual growth, ${ }^{30}$ Ethiopia's population is expected to reach 151.8 million by $2030 .{ }^{31}$ It is one of the world's poorest countries ${ }^{32}$ and in 2019 the World Bank, ${ }^{33}$ estimated its per capita income as much lower than the sub-Saharan African average of USD 1,551.5. ${ }^{34}$ With a per capita income of USD 850, Ethiopians earn USD 704.5 less than people in the remainder of Sub-Saharan Africa. ${ }^{35}$ In 2018, USD 4.9 billion of Ethiopia's income came from international aid, making it one of the world's largest recipients of such assistance. ${ }^{36}$

Until Prime Minister Abiy Ahmed came to power in April 2018, the Ethiopian developmental state held poverty eradication to be its primary mission and it was relatively stable. ${ }^{37}$ Ethiopia's two fiveyear Growth and Transformation Plans (GTPs) from 2010 to 2020 exemplify the developmental state at its best. Its success can be measured by the reduction in the poverty headcount ratio from $37.8 \%$ in 2004 to $23.5 \%$ in 2015 , representing a $15.2 \%$ reduction in ten years. ${ }^{38}$ With an annual increase of 3\% in 10 years between 2006 and 2016, Ethiopia improved its Human Development Index position by $45 \% .{ }^{39}$ Life expectancy at birth increased by 15.8 years, mean years of schooling increased by 0.7 years, expected years of schooling increased by 6.3 years and GNI per capita rose by $102 \% .^{40}$

Until recently, Ethiopia showed remarkable progress. One of the ten fastest-growing economies in the world, ${ }^{41}$ the country recorded annual double-digit growth rates for an entire decade (2005-2015),

27 The International Crisis Group (ICG) cites Ethiopia as third among its ten 'conflicts to watch' in 2020 and 2021. “Ten Conflicts to Watch in 2020," International Crisis Group, 27 December 2019: https://www.crisisgroup.org/global/10conflicts-watch-2020; "Ethiopia: What a disappointment," Amnesty International, 28 March 2018: https://www.amnesty. org/en/latest/campaigns/2018/03/ethiopia-what-a-disappointment/

28 “Ethiopia Country Profile," World Bank Group, 2019:https://data.worldbank.org/country/ethiopia

29 “Population Percentage below Age 14 in Ethiopia," World Bank Group, 2020: https://data.worldbank.org/indicator/ SP.POP.0014.TO.ZS?locations=ET

30 "Population Forecast for Ethiopia," International Futures at The Pardee Center, 2020: http://www.ifs.du.edu/ifs/frm CountryProfile.aspx?Country=ET

31 Ibid.

32 Ibid.

33 "Ethiopia Country Profile," op. cit.

34 Ibid.

35 Ibid.

36 Ibid.

37 Maru, Mehari Taddele, “The old EPRDF is dead, can its system be saved? Five steps to save the federation," op. cit.

38 "Ethiopia Country Profile," op. cit.

39 "Human Development Indices and Indicators: 2018 Statistical Update, Ethiopia," United National Development Plan, 2020: http://hdr.undp.org/sites/default/files/Country-Profiles/ETH.pdf

40 Ibid.

41 “Ethiopia's Great Run: The Growth Acceleration and How to Pace It," World Bank Group, February 2016: http://documents1.worldbank.org/curated/en/693561467988949839/pdf/99399-REVISED-PUBLIC-thiopia-EconomicUpdate-2-11-16-web.pdf 
making it Africa's fastest-growing non-oil producer. Despite deep worries regarding the sustainability of this growth, various agencies, including ones involved in international and regional development and financial institutions such as the World Bank and the IMF, confirmed Ethiopia's high economic growth rate. ${ }^{42}$ According to World Bank data, Ethiopia had a GDP growth rate of $8.7 \%$ in $2010 .{ }^{43}$ It registered 10.4\% growth in 2013, and in that year its GDP came close to USD 47 billion. (The positive effects of this growth were seriously diminished by high inflation, which in 2010 and 2011 reached more than 40\%.44) By 2018, Ethiopia's economy was expected to be one of Africa's top five ${ }^{45}$ and was anticipated to remain on this list for the next 40 years. If achieved, this would constituted an average annual per capita income growth rate of 3.65\%. Ethiopia was also appreciated for its efforts to meet the UN Millennium Development Goals (MDGs) and made great strides to reach its targets in health and education. In 2014, it was among the few countries in Africa that met the MDGs, ${ }^{46}$ Ethiopia achieved noteworthy results in pulling millions of its citizens out of severe poverty after the country began to implement its integrated development plans in 2002, as evidenced by the statistics cited above. ${ }^{47}$

Very significant improvements were seen in education. In 1994-1995 approximately three million pupils were in primary school but by $2008-2009$ this number had increased by more than $500 \%$ to 15.5 million. ${ }^{48}$ Ethiopia's predictive, preventive and responsive capabilities helped prevent droughts turning into famine and reduced the death toll.

These achievements have been attributed to the developmental state. Under the terms of the GTPs, the government ran the economy and public investment provided the foundation for the soft and hard infrastructure necessary for economic development. The government invested in essential infrastructure such as roads, railways, energy and water, and industries it defined as strategic for Ethiopia's development and stability, including, among others, information and communication, finance and banking, transportation, steel, metal engineering and sugar production. ${ }^{49}$ The government ran most public and some vital but traditionally private industries until a 2018 announcement that public businesses would be privatised..$^{50}$ During this period the state's main tasks were to support the development of large-scale commercial agriculture; create favourable conditions for and extend incentives for export-orientated and import-substituting industries, particularly sugar, textiles and cement; and enhance the expansion and quality of infrastructure, including roads, railways, electricity supply and telecommunications. ${ }^{51}$

\footnotetext{
42 Ibid.

43 Ibid.

44 "The Federal Democratic Republic of Ethiopia: Joint Staff Advisory Note on the Growth and Transformation Plan 2010/11-2014/15," International Monetary Fund, October 2011: https://www.imf.org/external/pubs/ft/scr/2011/cr11303. pdf

45 Ibid.

46 “Africa's Future and the World Bank's Support to it," World Bank Group, March 2011:

https://www.icafrica.org/fileadmin/documents/Knowledge/World Bank/1.Africa\%27s\%20Future\%20and\%20the $\% 20$ World\%20Bank\%27s\%20Support\%20to\%20It.pdf
}

47 "Ethiopia Country Profile," op. cit. https://data.worldbank.org/country/ethiopia

48 Engel, Jacob \& Rose, Pauline, "Ethiopia's progress on education: A rapid and equitable expansion of access." ODI. 13 July 2011: https://www.odi.org/publications/5058-ethiopias-progress-education-rapid-and-equitable-expansion-access

49 Weis, Toni. "Vanguard capitalism: party, state, and market in the EPRDF's Ethiopia," Doctoral Thesis: University of Oxford, 2015.

50 Bowker, John, "Ethiopia Pushes Privatization to Give Its Economy a Sugar Rush," Bloomberg, 21 January 2020: https:// www.bloomberg.com/news/articles/2020-01-21/ethiopia-s-privatization-push-aims-to-raise-7-5-billion

51 “GTP Vol. 2 Policy Matrix,” Ministry of Finance and Development, 2010. 


\section{Political Life}

On the political front, the now defunct Ethiopian Peoples' Revolutionary Democratic Front (EPRDF) ${ }^{52}$ overthrew the Mengistu military regime in 1991, and after four years of transition in 1995 multinational federalism was seen as the best constitutional instrument to bring peace and hold the country together. In 1995 the EPRDF promulgated a constitution that established a federation of linguisticcultural communities reflecting the social bases of the armed forces that had toppled the Mengistu regime. The EPRDF leadership believed that Ethiopia's peaceful economic development could only be achieved through a federal arrangement and protection from displacement due to land dispossession of the (overwhelmingly agrarian) population. The state owned the land, which is a natural resource as crucial for many African states as oil is for countries such as Libya. Through state land ownership and a federation policy, land met the core requirement of a natural resource employed in the interests of the developmental state. However, opposition political parties saw this as a policy to maintain power by controlling land - a vital source of livelihood for the overwhelming majority of Ethiopians.

Underlining the grave political challenges Ethiopia faced, in Mo Ibrahim's Index of African Governance report $2010^{53}$ Ethiopia ranked $35^{\text {th }}$ among the 53 countries on the continent with a score of 44 out of 100 (the top score being 83 for Mauritius and the lowest 29 for Chad). ${ }^{54}$ By 2020 Ethiopia ranked $31^{\text {st }}$ of the 54 countries with 46.6 out of 100, the top score then being 77.2 for Mauritius and the lowest 19.2 for Somalia. ${ }^{55}$ Ethiopia registered a 6.7 point overall improvement in governance in the last ten years while moving up four levels in the ranking. ${ }^{56}$ However, at 48.8, Ethiopia's overall governance level fell to 2.2 points lower than the average for significant peer countries. ${ }^{57}$ For safety and the rule of law, Ethiopia is still 1.6 points below the average of 49.5, but it improved (by 5.2 points) in 20052015. ${ }^{58}$ Indicative of Ethiopia's democracy deficit, political participation and human rights protection were 11.4 points lower than the average for African countries. ${ }^{59}$ In 2005-2015, overall performance in participation and human rights protection increased by 6.3 points. ${ }^{60}$ This does not take into account the low level of political competition that prevailed after the 2005 election.

In the same period, it was only for sustainable economic opportunities that Ethiopia scored (1.9 points) more than the average African country, but this rose by 5.6 points. ${ }^{61}$ For a developmental state, a continued decrease in the score would seriously weaken the government's main source of legitimacy: delivering sustainable economic opportunities.

From Success to Civil War

Since 1991 the Ethiopian leadership has tried to steadily steer the national ship and has done much to correct critical historical injustices and reduce poverty. However, in an attempt to redress the authoritarian legacy of the old EPRDF, the 2018 changes of government have shaken several of the pillars of the state's stability. Since 2020, civil war has been raging in Ethiopia, particularly in Tigray,

\footnotetext{
52 The EPRDF no longer exists. It was replaced by the centralised party system called Prosperity Party in 2019.

53 “Mo Ibrahim's Index of African Governance," Mo Ibrahim Foundation, 2010: http://peacewomen.org/sites/default/ files/wps ibrahimindexreport moibrahim october2011 0.pdf

54 Ibid.

55 “Ibrahim Index of African Governance (IIAG)," Mo Ibrahim Foundation, 2020: https://mo.ibrahim.foundation/iiag 56 Ibid.

57 Ibid.

58 Ibid.

59 Ibid.

60 Ibid.

61 Ibid.
} 
Oromia and Benishangul-Gumuz. ${ }^{62}$ The integrity of the state is now facing serious threats. How and why did this happen?

For decades, five main factors have determined Ethiopia's peace and security. These are first, a collective social psychology of uninterrupted statehood and state strength; second, the 1991 accession to power of the EPRDF coalition and its advocacy of a consensus-based federalism of cultures; third, economic delivery that brought performance popular legitimacy; fourth, support from the international community; and lastly, the threat posed by forces hostile to Ethiopia. Save for the first, all the other pillars have been weakened.

The cohesiveness of the security sector, in particular, has been threatened. Security forces (the military, police forces at federal and regional level, the intelligence agencies) have become politicised and their cohesion affected by the weakening of the relationship between the federal government and regional states. In some cases, it has become broodingly confrontational, leading to wars in Tigray, Oromia, Benishangul Gumuz, and some parts of Amhara. The army cracked when it was involved in massive war on Tigray where now the federal army and security sector has been cleansed of Tigrayan officers. As for the intelligence apparatus, the National Intelligence and Security Agency (NISA) has been hit hardest by the transition. It has been institutionally paralyzed. As a result, NISA at present does not have the reach it once enjoyed in many parts of the country.

The challenges in the security sector are partly a result of the paralysis within the dominant ruling party. Under the EPRDF's earlier relatively cohesive and well-managed party, Ethiopia enjoyed relative peace and security; the ruling party's strength stemmed from its democratic centralism that ensured indirect control and command over the regional states. The legitimacy of its performance in terms of economic delivery and constitutional protection of cultural communities constituted an additional source of strength.

Now, however, the old coalition system is ideologically dead beyond resuscitation and its capacity to serve as pillar of stability and national unity is over. While the EPRDF has established strong protections for cultural communities and has enjoyed some performance legitimacy, its limited social base has meant that it lacks a degree of popular legitimacy. Consequently, the past three decades have been marked by recurrent protests and associated social instability. The 2018 transition process was hoped to bring peace and democracy to the country, but the transition neither achieved peace and democracy, nor the economic delivery that Ethiopia enjoyed for decades. It rather spawned new and more dangerous wars.

Furthermore, rivalry on the Nile with Egypt and pressure from great powers competition between USA and China in the Red Sea and the Horn of Africa and Yemen have increased, significantly undermining the sovereignty of countries in the region. ${ }^{63}$

62 Walsh, Declan and Latif Abdi Dahir,"Why is Ethiopia at war with itself?" New York Times, 5 November 2020: https:// www.nytimes.com/2020/11/05/world/africa/ethiopia-tigray-conflict-explained.html

63 Maru, Mehari Taddele, "The old EPRDF is dead, can its system be saved? Five steps to save the federation," op. cit. 


\section{Rwanda}

Economic and Political Achievements

Rwanda is Africa's fastest-growing country. ${ }^{64}$ Nowhere on the continent is the impact of economic growth and development so visible. Transforming a country so scarred by civil war and genocide into an exemplary developmental state is a monumental African success that should be trumpeted throughout the continent.

Rising from the ashes of the 1994 genocide of the Tutsis, Rwanda exhibits most of the features of a developmental state, namely stability, a dominant ruling party, visionary leadership, ${ }^{65}$ a transformative developmental agenda ${ }^{66}$ and effective public bureaucracy. ${ }^{67}$ Since 1994, President Paul Kagame, now in his third seven-year term, has remained the leader of the Rwandan Patriotic Front, controlling an absolute majority. ${ }^{68}$ With the aspiration to reach middle income country status by 2035 , Rwanda's National Strategy for Transformation and Economic Development and Poverty Reduction Strategy (EDPRS) led to an average 7.2 percent GDP and 5 percent per capita growth for well over a decade until 2018. In 2019, growth stood at 10 percent. The development is mainly a result of public-sector expenditure that led to a solid improvement in living standards ${ }^{69}$ During the past two decades, the Rwandese developmental state has achieved more than a 75 percent drop in mortality, 100 percent primary school enrolment and 50 percent poverty reduction. Life expectancy at birth improved from 29 in 1994 to 69 in $2019 . .^{70}$ Nevertheless, Rwanda's remarkable economic performance has come at the cost of mounting debt. ${ }^{71}$

Rwanda faces other kinds of challenges that are usual for developmental states. ${ }^{72}$ One of these relates to democracy and a peaceful transition of power in a political system with a dominant ruling party. In the absence of a strong leader at the centre, the country may descend into instability and chaos, like what followed the death of Meles Zenawi, the architect of the Ethiopian developmental state. ${ }^{73}$ Moreover, as in other developmental states such as Ethiopia, ${ }^{74}$ public enterprises and private sector

64 "The World Bank in Rwanda: Country Overview," World Bank Group, 2021: https://www.worldbank.org/en/country/ rwanda/overview

65 Crisafulli Patricia. and Redmond Andrea, Rwanda Inc.: how a devastated nation became an economic model for the developing world, Palgrave Macmillan: New York, 2012.

66 Malunda, Dickson and Musana, Serge, "Rwanda Case Study on Economic Transformation," Institute of Policy Analysis and Research - Rwanda, 2012: http://ipar-rwanda.org/IMG/pdf/acet_report.pdf

67 Evans, Peter, "In search of the 21st-century developmental state." The Centre for Global Political Economy, 2008.

68 “The World Bank in Rwanda.", op. cit.

69 Takeuchi, Shinichi "Development and Developmentalism in Post-genocide Rwanda, in Takagi Y., Kanchoochat V. and Sonobe T. (eds.) Developmental State Building. Emerging-Economy State and International Policy Studies, Springer: Singapore, 2019.

70 “The World Bank in Rwanda." op. cit.

71 Pritish Behuria, “The Tentative Developmental State in Rwanda: From Anti-Manufacturing to Recapturing the Domestic Market,” LSE Blogs, 2016: https://blogs.lse.ac.uk/internationaldevelopment/2016/09/30/the-tentative-developmentalstate-in-rwanda-from-anti-manufacturing-to-recapturing-the-domestic-market/

72 Keffler, Natalie, "Economic growth in Rwanda has arguably come at the cost of democratic freedom." World Finance, 2019: https://www.worldfinance.com/markets/economic-growth-in-rwanda-has-arguably-come-at-the-cost-ofdemocratic-freedom

73 Andrew Friedman, “Kagame's Rwanda: Can an Authoritarian Development Model be Squared with Democracy and Human Rights?”, Oregon Review of International Law, Vol. 14, Issue 1, 2012.

74 Weis, Toni, "Ethiopia's Vanguard Capitalists: How the EPRDF Mobilizes for Economic Development," Foreign Affairs, 26 May 2016: https:/www.foreignaffairs.com/articles/ethiopia/2016-05-26/ethiopias-vanguard-capitalists 
actors affiliated with the Rwandese Patriotic Front play a critical role in the fast economic growth ${ }^{75}$ and they are privileged in the economy, including in terms of access to public contracts. ${ }^{76}$

The 2020 Mo Ibrahim Index of African Governance report ranked Rwanda eleventh out of 54 countries on the continent ${ }^{77}$ and its ten-year (2005-2016) country trend ranked seventh. ${ }^{78}$ Rwanda ranked fourth for economic opportunities and tenth for human development, affirming the significant development growth it has achieved. ${ }^{79}$ Indicative of the grave political challenges it faces, Rwanda ranks thirty-first for participation, rights and inclusion. For security and rule of law it ranks eleventh. ${ }^{80}$ Rwanda is much less heterogenous than Ethiopia. It suppressed ethnic-based political mobilisation to the extent that ethnicity-related political expression is banned. ${ }^{81}$ This contrasts with the constitutional guarantee of self-determination and self-rule for ethnic communities in Ethiopia. ${ }^{82}$

\section{A Developmental State from the Ashes of Genocide}

Rwandan political development is a legacy of the tragic history of the 1994 genocide against its Tutsi population and the political discourse that preceded it. Considerations of Rwanda need to begin by recognising the extraordinary challenges the country faced following the 1994 genocide of the Tutsis. The genocide framed Rwanda's political, economic and even social development. With that history in mind, Rwanda's political and economic resuscitation and development cannot be considered a 'normal' democratisation and nation-building process.

Rwanda's particular history and recent developments do not easily yield to an archetypal assessment of democratisation and the state-building process. The country's historical particularities make stability as necessary for development as democracy is. Hence the critical importance of effective government. With this particular circumstance as background, it is remarkable that after two decades Rwanda has managed to extricate itself from the debilitating economic effects of the genocide and has become an example of a successful African developmental state.

The genocide is not only a historical fact informing Rwandan socio-political development but also a predominant truth in the public sphere. Fear looms large in the calculus of Rwandan politics. In a poor country with such a troubled history, thousands of things can go wrong. Fear of ethnic conflict is understandable, and concerns about the unpredictability of democracy are justifiable. Petrified by concerns about a possible second genocide, a significant percentage of Rwandans justify the government's restrictions on democracy as legitimate and proportionate. Consequently, many Rwandans prefer stability and delivery of public goods to democracy, an attitude partially attributable to fear of politics and the politics of fear.

It is true that restrictions on some aspects of democracy in Rwanda might be justifiable or even necessary. In the aftermath of the genocide and the mass media's role in the killings, stricter curbs on freedom of expression, particularly freedom of the media, remain an unfortunate political trend.

75 Gokgur, Nilgun, "Rwanda's ruling party-owned enterprises: do they enhance or impede development," Institute of Development Policy and Management, University of Antwerp: Antwerp, 2012.

76 Ibid.

77 "Ibrahim Index of African Governance (IIAG)," op. cit.

78 “The 2016 Ibrahim Index of African Governance: Key Findings," op. cit.

79 "Ibrahim Index of African Governance (IIAG)," op. cit.

80 Ibid.

81 Hintjens, Helen,"Post-genocide identity politics in Rwanda." Ethnicities, Sage Publications, 2011: https://hal.archivesouvertes.fr/hal-00571890/document

82 Maru, Mehari Taddele, "Federalism and Conflicts in Ethiopia," Africa Insight, March 1, 2010: https://hdl.handle. $\underline{\text { net/10520/EJC17614 }}$ 
Critics also found Kagame's third-term presidency legally and normatively unjustifiable. Indeed, since the end of the Cold War, the age of lifelong African presidencies has ended, and they remain widely unpopular.

\section{Shortcomings of the developmental state model in the cases of Ethiopia and Rwanda}

These examples show that the developmental state has two cardinal shortcomings: first, state hegemony instead of democratic plurality; and second - a result of the first - weak accountability of a government that is heavily dependent on personality and party oversight, instead of democratic institutional accountability.

In both Ethiopia and Rwanda, developmental states have been effective in their delivery of public services and economic development (although less so in the spheres of politics and democracy). As a result, their governments have generally enjoyed performance legitimacy. Both countries have been led by dominant parties, which are critical for developmental states.

At the centre of the transformation of the Rwandan economy and the country's security are the governing RPF and President Paul Kagame, while in Ethiopia it was the EPRDF and its leader, Meles Zenawi. The World Bank called this model “The Ethiopian Way." For developmental service delivery, perhaps aptly, the EPRDF and the RPF looked to the east for inspiration. While Japan, South Korea, Singapore, Taiwan, Hong Kong, Thailand, Indonesia, Malaysia and China are most often considered the premier developmental states, China and South Korea provided the inspirational blueprint on which the EPRDF based its economic model, with some adjustments in the light of Ethiopia's historical, cultural and other national particularities. ${ }^{83}$

The developmental states in Ethiopia and Rwanda became viscerally hostile to accountability and the rule of law. While democracy, as generally understood, is designed more to handle differences than similarities and assumes that all officials and parties, including presidents and ruling parties, are replaceable, in a developmental state there is a monopolistic exercise of power. Each developmental state has had an authoritarian or Marxist-leaning dominant party at some time in its history. Hence the developmental state can lead to a political party 'imperium' which exercises state power as a monopolistic hegemon. Like Ethiopia and Meles Zenawi, Rwanda is known for its rapid economic growth and its long-serving president, Paul Kagame. Labelled by many media outlets as one-horse races, elections in both countries have been led by dominant ruling parties: Ethiopia under Zenawi and Rwanda under Kagame offered participatory but uncompetitive space. The ruling parties in both countries and their leadership have been accused by opposition parties both at home and abroad of violating human rights and stifling critical power contenders. ${ }^{84}$ International media, human rights organisations and intergovernmental bodies such as the UN and the EU have expressed their opposition to the governance style in Ethiopia and Rwanda. ${ }^{85}$

Dynamism and pragmatism are two essential pillars of the developmental state. With a growing

83 Maru, Mehari Taddele, "Why Africa Loves China," Aljazeera, 6 January 2019: https://www.aljazeera.com/ opinions/2019/1/6/why-africa-loves-china

84 "Rwanda Events of 2019," Human Rights Watch, 2020: https://www.hrw.org/world-report/2020/country-chapters/ rwanda\#; "European Parliament resolution of 21 January 2016 on the situation in Ethiopia (2016/2520(RSP))," Office Journal of the European Union, 12 January 2018: https://eur-lex.europa.eu/legal-content/EN/TXT/ PDF/?uri=CELEX:52016IP0023\&from=EN

85 “Addressing the Pervasive Human Rights Crisis in Ethiopia: Letter to the UN Human Rights Council," Human Rights Watch, 2 June 2017: https://www.hrw.org/news/2017/06/02/addressing-pervasive-human-rights-crisis-ethiopia; Kibii, Eliud, "UK, US raise concern over human rights violations in Rwanda." The Star, 30 January 2021: https://www.the-star. co.ke/news/africa/2021-01-30-uk-us-raise-concern-over-human-rights-violations-in-rwanda/ 
middle class and the strength of popular demands, the Ethiopian developmental state failed to reflect demographic trends. Protests that followed the death of Zenawi, the architect of the Ethiopian developmental state, led to a change of leadership that favoured a neo-liberal ideology, which caused a schism within the ruling party. The Ethiopian constitutional system failed to manage differences within the ruling party, leading to civil war in the country. While its progress is commendable ${ }^{86}$ Ethiopia's developmental state lagged behind in democratisation, a deficit that caused continual protests and now a civil war. The fate of Rwanda may be no different unless its politics are rapidly democratised. This is in addition to geopolitical competition from great powers in Africa that could affect its fate. ${ }^{87}$

Ethiopia's recent civil war might offer lessons for Libya as an aspiring developmental state. It shows the need for robust and reliable democratic constitutionalism guided by the rule of law. Neither a dominant political party nor a strong leader can substitute a vibrant constitutional democracy in which power is exercised with legitimacy, the majority of the citizenry have the right to rule and the rights of minorities are fully respected. Like socio-economic development, democratic accountability increases tolerance of diversity and plurality. An empowered democratic citizenry is central to increasing the accountability of officials through constitutional democratic institutions. On the contrary, a fixation on stability at any cost can jeopardise future social developments and even the state's viability. Similarly, Libya's post-war generation will increasingly require leadership that thrives on freedom, not fear.

\section{Part Three: Lessons for Libya}

There is no generic roadmap for a developmental state. Each country embarking on the developmental journey needs to design its own version of the road to economic success. However, there are some practical lessons Libya can emulate from developmental state experiences.

\section{Possible Interpretations of the Developmental State Model in Libya}

\section{A Post-Conflict Reconstruction and Development (PCRD) Plan}

In the Libyan context, a developmental state would mean a transition to post-conflict reconstruction and development (PCRD). A successful PCRD plan in a developmental state covers essential development factors: stability, a confederative arrangement, ${ }^{88}$ ownership, and political and financial autonomy to utilise key natural resources. In Libya, a developmental state could involve the implementation of a Marshal Plan approach (similar to Europe after the Second World War). Priority in the PCRD plan should be given to preventing a lapse into conflict or war. The plan needs to be inclusive and comprehensive in its interventions, aiming for stabilisation, nation-building, statebuilding, democracy-building, ${ }^{89}$ human security, recovery and rehabilitation, constructing public service infrastructure and leading to inclusive governance and sustainable development. In the Libyan context, and to a large extent in other post-war reconstruction projects, a developmental state would entail rebuilding the state with enormous capabilities to deliver, to distribute public services and develop goods infrastructure with inclusivity in a way that bestows legitimacy, that enhances security provision, and more importantly that owns and utilises its natural and other resources more effectively.

Broadly speaking, a PCRD plan covers the sequencing of interventions involving security, development

86 "Ethiopia's Great Run: The Growth Acceleration and How to Pace It," op. cit.

87 Wehrey, Frederic, op. cit.; Maru, Mehari Taddele. 2018. "Why the US is engineering political change in East Africa," op. cit.

88 Elazar, Daniel J, 1995. Federalism: An Overview. Pretoria: HSRC Publishers: Pretoria, 1995.

89 Jabareen, Yosef. 2013. Conceptualizing "Post-Conflict Reconstruction" and "Ongoing Conflict Reconstruction" of Failed States, International Journal of Politics, Culture and Society. Vol. 26, 2012. 
and democracy.90 The sequencing precisely corresponds with the developmental state's vital priorities and intersects with the African Union (AU)'s PCRD policy. ${ }^{91}$ The AU defines a PCRD plan as "a comprehensive set of measures that seek to address the needs of countries emerging from conflict, including the needs of affected populations; to prevent escalation of disputes; to avoid a relapse into violence; to address the root causes of conflicts, and consolidate sustainable peace." ${ }^{92}$ Increasingly, PCRD is construed to mean building a modern state with inclusive governance that can prevent state failure and provide security and public goods. ${ }^{93}$ In a situation such as that in Libya, PCRD should aim to build or re-establish the state's architecture, including juridical statehood and security sector reform through democratic civilian control of the armed forces and the participation of civil society. For this reason, structuring the governance and political space is critical for successful PCRD.

In the short term, democracy and the rule of law may slow the formation of a strong, capable and authoritative state. However, sustainable governance requires constitutional democracy with inclusive participation and strict accountability, particularly in the armed forces. In this way, Libya may achieve a degree of stability and build a developmental state that represents the long-term aspirations of its citizens. Given the high level of competition among external forces in Libya ${ }^{94}$ the heavy focus of the developmental state on autonomy may help tame the interests of regional and extra-regional actors. Neutrality in its foreign policy stance may also help seal off unnecessary continued interference in Libya, as in the Cold War era. ${ }^{95}$

\section{State Security and Defence}

A successful developmental state requires a semblance of stability. Stability allows resources to be earmarked for state development, which boosts the state's popular and performance legitimacy in the eyes of the citizens. While a transition to stability in Libya will require a strong security sector, sustainable peace will be achieved essentially through political cooperation among various legitimacy centres and constituencies. In fact, a developmental state begins with the assumption that the best source of legitimacy and consolidation of the state is socially driven economic and social delivery with a limited role for the security sector, including the military. In a developmental state, the armed forces should not dictate politics, in fact the reverse should be the case. Therefore, the country's security and defence policy is subservient to the developmental role of the state, and the budgetary and resource allocation to the armed forces is guided by developmental principles. In turn, the security and defence policy should determine the unification and formation of one army. States first need minimum effective coercive power before they can focus on the development of public goods, as happens in a developmental state. In this regard, a developmental state will prioritise the unification and accountability of the command, control and communications among armed elements. It will also focus on building minimum capacity to bring all means of violence and coercion under the state's authority. The priority for such a government is defending the country from external threats.

90 Fukuyama, Francis, Nation Building: Beyond Afghanistan and Iraq, John Hopkins University Press, 2006; Fukuyama, Francis, "Liberalism Versus State-Building," Journal of Democracy, Vol. 18, Issue 3, 2007; Huntington, Samuel, Political Order in Changing Societies, Yale University Press, 1968; Diamond, Larry, "What Went Wrong and Right," in Fukuyama, Francis (ed) Nation-building: beyond Afghanistan and Iraq, John Hopkins University Press, 2006, p.173-195; Zakaria, Fareed, The Future of Freedom: Illiberal Democracy at Home and Abroad, W. W. Norton and Company: New York, 2003.

91 "Policy on Post Conflict Reconstruction and Development", African Union, July 2006: https://www.un.org/en/africa/ osaa/pdf/au/policy postconflict dev reconstruction 2006.pdf

92 Ibid.

93 Herbst, Jeffrey, “African Militaries and Rebellion: The Political Economy of Threat and Combat Effectiveness," Journal of Peace Research, Vol. 31, Issue 3, 2004, p 357-369.

94 Wehrey, Frederic, op cit.

95 Maru, Mehari Taddele, "A New Cold War in Africa," Aljazeera, 1 July 2019: https://www.aljazeera.com/

opinions/2019/7/1/a-new-cold-war-in-africa 


\section{Confederative Governance}

A developmental state in Libya may mean more confederative governance with less central government and a more decentralised (loose federal) system. The developmental state could be defined as a transitional process of governance that phases itself out as it moves to a vibrant democracy. From this perspective, a degree of regional autonomy and recognition of and response to group-based grievances are crucial for the developmental state to last. The new Presidential Council and head of the Government of National Unity (GNU) elected by the Libyan Political Dialogue Forum (LPDF) in February 2021 have confederative elements. ${ }^{96}$ In the absence of a monopoly of force, as in Libya, a confederal arrangement would allow peace to be built by bringing dispersed centres of legitimacy into one polity. Confederation has some roots in the 1951 constitution reviving three autonomous provinces. ${ }^{97}$ In light of the absence of monopoly over the use of force and the presence of significant foreign interference, the risk of fragmentation and unwarranted external interference could be posed as primary concerns associated with a confederation. However, the confederative arrangement may help hold the country together in the face of destructive centrifugal forces and external interference. At least for now and the foreseeable future, a confederal system of government would seem to offer the best chance of achieving some degree of durable stability. Cooperation among constituencies willing and capable to provide effective security and some level of accountability may form zones of authority that also guarantee a level of durable stability. This arrangement may also help devolved resource allocation, offering incentives for local authorities to exploit their proximity and local expertise. ${ }^{98} \mathrm{With}$ local authorities taking responsibility for the provision of their security, most of the state's resources and energy would be employed for its developmental functions. In addition to consolidating existing pockets of stability and law and order, such a confederative arrangement would release resources otherwise destined for the military.

\section{Resource Governance}

Another important aspect of Libya's developmental state would be the ownership and autonomy to utilise key natural resources (oil and gas) for human development. The governance of natural resources and distributive justice are two further essential elements of the developmental state. Given the sizeable public expenditure involved in this process, ${ }^{99}$ ownership and much of the control and use of natural resources would be critical. ${ }^{100}$ PCRD in general heavily relies on the mobilisation of resources from external sources. This should not be the case in Libya as it is one of the ten countries with the largest proven oil reserves. Although oil dependence is a challenge in itself and does not guarantee sustainable revenue and development, oil and gas would be extremely important national assets for launching a successful post conflict reconstruction and development plan. Such an approach would allow Libya to build delivery capacity and constitutional accountability.

96 Eljarh, Mohamed, op. cit. 2021; "Secretary-General Welcomes Libyan Political Dialogue Forum's Selection of Temporary Executive Authority, Calls upon All Parties to Respect Tunis Road Map," United Nations Meetings Coverage and Press Releases, 5 February 2021: https://www.un.org/press/en/2021/sgsm20572.doc.htm.

97 Walsh, Declan. "A Radical Idea to Rebuild a Shattered Libya: Restore the Monarchy", The New York Times, 25 May 2016: https://www.nytimes.com/2016/02/25/world/middleeast/a-radical-idea-to-rebuild-a-shattered-libya-restore-themonarchy.html

98 Maru, Mehari Taddele, "Rethinking the North African Uprisings." African Union Herald, Vol. 2, 2012: https:// meharitaddele.info/wp-content/uploads/2012/11/AU Herald Design Volume 02 09.pdf

99 "Libya Economic Monitor," op. cit.

100 Wehrey, Frederic, op. cit., Maru, Mehari Taddele, "Rethinking the North African Uprisings, " op. cit. 


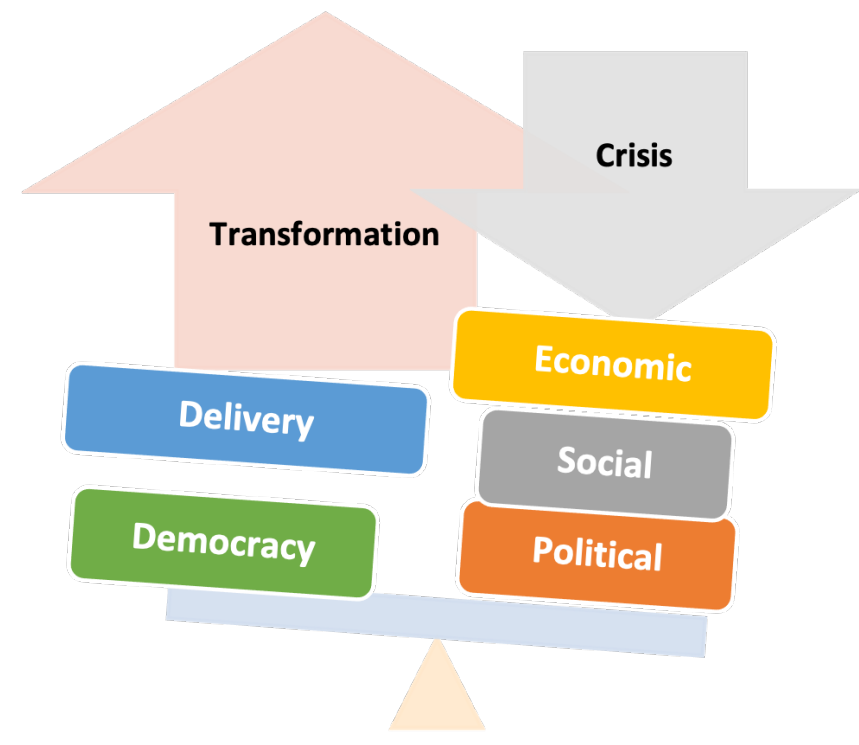

Transformation Outpacing and Crisis (Mehari Maru, 2014)

Nonetheless, there would appear to be two major challenges involved in establishing a developmental state in Libya. The first is the need to exercise sovereignty over natural resource governance (oil and gas); the second is a lack of consensus among the Libyans. The current fragmentation of the domestic elite and its constituencies allows unwarranted interference by external actors, ${ }^{101}$ which could undermine Libya's policy sovereignty, including control over its natural resources. As an antidote, reconstruction, social justice and poverty reduction could be gathered into an agenda that would rally many Libyans to its cause. In which case, a post-conflict developmental Libyan state would centre its policies on post conflict reconstruction and development.

\section{Conclusions: Key Requirements for a Developmental State Model in Libya}

Libya needs a fast-paced transformation to make up for lost decades in its development. A developmental state is probably the most effective means of achieving the scale, depth, extent and pace of change necessary for Libya. However, such a transition requires meeting many preconditions. Chief among these are:

a. A long-term vision and an irreplaceable role for the state's political economy in the postconflict reconstruction and development of Libya.

b. Extensive control and use of natural resources, especially oil and gas, for the benefit of all Libyans.

c. A determined elite offering disciplined leadership with broad-based consensus.

d. Effective state capacity to deliver public goods, implement plans and execute decisions.

e. A strong professional meritocratic bureaucracy.

f. The private sector and civil society being subordinate to the long-term vision of the state.

101 Wehrey, Frederic, op. cit.; "Libya Economic Monitor," op. cit. 
Libya's chances of establishing a developmental state depend on three factors: political developments that allow the emergence of a dominant coalition party; public ownership and governance of oil and gas resources; and significant confederative (or federative) autonomy of the regions in political matters.

Needless to say, in its current situation Libya is yet to meet the main preconditions for envisioning a developmental state. Visionary elite consensus, a dominant ruling party with the potential to gain and retain power for a long period of time or a meritocratic bureaucracy do not exist in today's Libya. Rarely do developmental states begin their journey possessing all the elements necessary for success. In practice, such states have to create the necessary and sufficient conditions for launching a developmental state. This is why there is no generic roadmap towards a developmental state to follow. These elements have to be invented by the Libyans. The current government and all other Libyan forces with constituencies of various kinds (the private sector and religious, traditional and civil society) now need to broaden the transitional tent of inclusivity by calling a much-needed national constitutive conference. In addition to deliberating on the country's constitutional design, such a constitutive conference may help cede powers to a strong governance body at the national level. Furthermore, the conference would need to agree on a constitutional arrangement in which the terms of the highest offices are long enough to make substantive changes and in which political contestations are limited to a short election time. Both stability and legitimacy should be pursued together without sacrificing legitimacy for the sake of stability. A confederative arrangement may help keep the equilibrium between stability and legitimacy.

\section{Political Legitimacy and Political Continuity}

It is essential to emphasise that developmental states cannot succeed without a lasting commonly shared vision. Their effectiveness in delivering public goods depends on ethical and disciplined leadership. Most developmental states are characterised by one dominant party that remains in power over time. Hence a developmental state requires decades-long uninterrupted hegemonic political control. In 'normal' liberal states, on the other hand, the changes in government and policies that follow each election cycle make such continuous exercise of authority and policy continuity difficult.

In addition, developmental states give precedence to delivering public services over democracy. Furthermore, with an extraordinary fusion of power in the hands of leaders, state legitimacy rests on the willingness of the party and its leadership to hold themselves accountable. Subsequently, governance of a developmental state requires an exceptionally enlightened political and economic elite that is prudent in its actions and supports some degree of trade-off between democracy and delivery.

For this reason, developmental states require political consensus and a shared sense of urgency directed towards transformation, which becomes problematic should the country's political, military and economic elite be badly fragmented as in today's Libya. Given the current extensive interference by external actors in Libyan affairs, the state's policy sovereignty is likely to be undermined. Hence, the Libyan leadership needs to be determined to implement agreements with a steady hand and leave behind routine political skirmishes in the interests of its long-term vision. Furthermore, it might prove almost impossible to maintain a neutral foreign policy in the presence of the various global powers and regional rival forces competing to shape the country's future and its resources. By forging a national consensus, Libya's developmental state could solve the continual external interference and allow the state to exercise one of its essential features: autonomy. With such a national consensus, the ownership and extensive control and use of natural resources (such as oil) would be critical to the delivery of public goods in a Libyan developmental state. 
In Libya, the main challenges in forming such a state arise from the absence of broadbased political agreement among the elite and the lack of a dominant political party. To sustain a developmental state, a critical mass of political and economic interests must arrive at a common vision of the developmental state. In this regard, a critical problem in implementing a developmental state would be the absence of a single dominant party that can win elections successively. Alternatively, to build a developmental state, the Libyan elite and their constituencies need to forge a consensus that looks beyond the immediate impact of regular elections and focus on the welfare of future generations. This consensus may not be readily available after a long civil war.

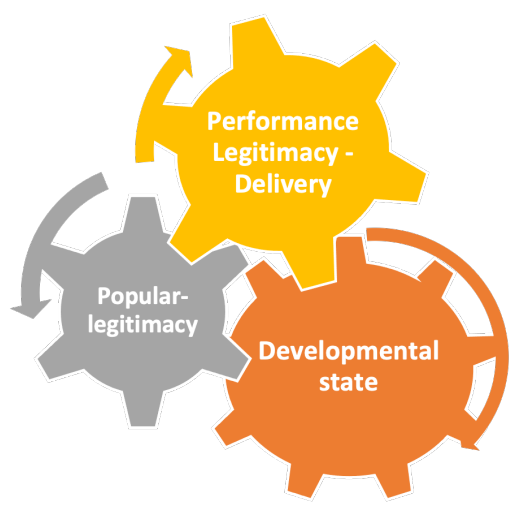

Popular and Performance Legitimacy (Mehari Maru, 2014)

\section{Agreement on Political and Economic Vision}

However, the most evident lessons from the experiences of developmental states, particularly Ethiopia and Rwanda, emanate from the pitfalls of the developmental state. At the same time, if Libya were to adopt the developmental state model, it would need to create inbuilt constitutional mechanisms to address the major shortcomings of the model.

If Libya were to adopt the developmental state model elements, it would require a solid meritocratic bureaucracy capable of effectively implementing the leadership's plans, which Libya needs to build quickly. In this way, the Libyan state would become an autonomous polity capable of bringing economic and political transformation through compromise among the political elite and undertaking massive service delivery programmes. The private sector and civil society would each need to have a role defined with elite consensus and complementary to that of the state.

A developmental state needs to be equipped with a telescope for long-distance vision and a microscope to scrutinise the fundamentals. Libya needs the foresight to focus on building the state's superstructure, but importantly it also requires a strong foundational state substructure. A developmental state centred on consensus-based constitutional state-building, inclusive post-conflict reconstruction and development and distributive social justice may offer some perspectives on how to build that foundation while democratic governance concentrates on the long-distance superstructure.

Initially, a developmental state model may promote delivery of public goods and democracy. Moreover, efficient delivery of public goods may generate performance legitimacy that foster state -society relations. However, it should be introduced by design, not by default. Hence it would require overall political consensus among the Libyan elite. Whether or not this is achievable is a question best left to the Libyans themselves. 


\section{References}

African Union, "Policy on Post Conflict Reconstruction and Development," July 2006: https://www. un.org/en/africa/osaa/pdf/au/policy postconflict dev reconstruction 2006.pdf

Amnesty International, "Ethiopia: What a Disappointment", 28 March 2018: https:// www.amnesty.org/en/latest/campaigns/2018/03/ethiopia-what-a-disappointment/ Andrew Friedman, "Kagame's Rwanda: Can an Authoritarian Development Model be Squared with Democracy and Human Rights?" Oregon Review of International Law, Vol. 14, Issue 1, 2012.

Bowker, John, "Ethiopia Pushes Privatization to Give Its Economy a Sugar Rush," Bloomberg, 21 January 2020: https://www.bloomberg.com/news/articles/2020-01-21/ethiopia-s-privatizationpush-aims-to-raise-7-5-billion

Bresser-Pereira, Luiz Carlos, "Models of the Developmental State," CEPAL Review, August 2019: https://www.cepal.org/en/publications/44978-models-developmental-state

Crisafulli, Patricia and Redmond, Andrea, Rwanda Inc.: how a devastated nation became an economic model for the developing world, Palgrave Macmillan: New York, 2012.

Diamond, Larry, "What Went Wrong and Right", in Fukuyama, Francis (ed.) Nation-building: beyond Afghanistan and Iraq, John Hopkins University Press, 2006, p. 173-195.

Eaton, Tim, "Libya's War Economy: Predation, Profiteering and State Weakness," Chatham House/ The Royal Institute of International Affairs, 12 April 2018: https://www.chathamhouse.org/2018/04/ libyas-war-economy-predation-profiteering-and-state-weakness

Elazar, Daniel J, 1995. Federalism: An Overview. Pretoria: HSRC Publishers: Pretoria, 1995. Engel, Jacob \& Rose, Pauline, "Ethiopia's Progress on Education: A Rapid and Equitable Expansion of Access." ODI, 13 July 2011: https://www.odi.org/publications/5058-ethiopias-progress-education-rapid-and-equitable-expansion-access

Evans, Peter, "In search of the 21st-century developmental state." The Centre for Global Political Economy, 2008.

Fukuyama, Francis, "Liberalism Versus State-Building," Journal of Democracy, Vol. 18, Issue 3, 2007.

Fukuyama, Francis, Nation Building: Beyond Afghanistan and Iraq, John Hopkins University Press, 2006.

Gay, John, “Development as Freedom: a virtuous circle?” Afrobarometer, 2003: https://afrobarometer. org/publications/wp29-development-freedom-virtuous-circle

Gokgur, Nilgun, "Rwanda's ruling party-owned enterprises: do they enhance or impede development," Institute of Development Policy and Management, University of Antwerp: Antwerp, 2012.

Herbst, Jeffrey, "African Militaries and Rebellion: The Political Economy of Threat and Combat

Effectiveness," Journal of Peace Research, Vol. 31, Issue 3, 2004, p. 357-369.

Hintjens, Helen,"Post-genocide identity politics in Rwanda." Ethnicities, Sage Publications, 2011: https://hal.archives-ouvertes.fr/hal-00571890/document 
Huntington, Samuel, Political Order in Changing Societies, Yale University Press, 1968. International Crisis Group, "Of Tanks and Banks: Stopping a Dangerous Escalation in Libya," 20 May 2019: https://www.crisisgroup.org/middle-east-north-africa/north-africa/libya/201-tanks-and-banks-stopping-dangerous-escalation-libya International Crisis Group, “Ten Conflicts to Watch in 2020”, 27 December 2019: https://www. crisisgroup.org/global/10-conflicts-watch-2020

International Futures at The Pardee Center, "Population Forecast for Ethiopia," 2020: $\quad$ http://www.ifs.du.edu/ifs/frm CountryProfile.aspx?Country=ET International Monetary Fund, "The Federal Democratic Republic of Ethiopia: Joint Staff Advisory Note on the Growth and Transformation Plan 2010/11-2014/15," October 2011: https:// www.imf.org/external/pubs/ft/scr/2011/cr11303.pdf

Jabareen, Yosef. 2013. Conceptualizing "Post-Conflict Reconstruction” and "Ongoing Conflict

Reconstruction” of Failed States, International Journal of Politics, Culture and Society, Vol. 26, 2012.

Keffler, Natalie, "Economic growth in Rwanda has arguably come at the cost of democratic freedom." World Finance, 2019: https://www.worldfinance.com/markets/economic-growth-in-rwandahas-arguably-come-at-the-cost-of-democratic-freedom

Konrad Adenauer Stiftung, “Inside Libya," February 2021: https://www.kas.de/documents/282499/282548/INSIDE+LIBYA+January+Editi.pdf/8c9cab27-2628-2fb6-5703-647d5a $\underline{5 c 66 d f ? \text { version }=1.0 \& \mathrm{t}=1612256132148}$

Malunda, Dickson and Musana, Serge, "Rwanda Case Study on Economic Transformation," Institute of Policy Analysis and Research - Rwanda, 2012: http://ipar-rwanda.org/IMG/pdf/acet report. pdf

Maru, Mehari Taddele, "A New Cold War in Africa," Aljazeera, 1 July 2019: https://www.aljazeera. com/opinions/2019/7/1/a-new-cold-war-in-africa

Maru, Mehari Taddele, "Rwanda and President Kagame," Aljazeera Centre for Studies, 9 September 2017: https://studies.aljazeera.net/en/reports/2017/09/rwanda-president-kagame-170909121048238. $\underline{\mathrm{html}}$

Maru, Mehari Taddele, "The old EPRDF is dead, can its system be saved? Five steps to save the federation," Ethiopia Insight, 3 October 2018: https://www.ethiopia-insight.com/2018/10/03/the-oldeprdf-is-dead-can-its-system-be-saved-five-steps-to-save-the-federation/

Maru, Mehari Taddele, "Why Africa Loves China," Aljazeera, 6 January 2019: https://www.aljazeera. com/opinions/2019/1/6/why-africa-loves-china

Maru, Mehari Taddele, "Why the US is engineering political change in East Africa," Aljazeera, 9 October 2018: https://www.aljazeera.com/opinions/2018/10/9/why-the-us-is-engineering-political-change-in-east-africa

Ministry of Finance and Development, “GTP Vol. 2 Policy Matrix,” 2010.

Mo Ibrahim Foundation, “Ibrahim Index of African Governance (IIAG)," 2020: https://mo.ibrahim. foundation/iiag

Mo Ibrahim Foundation, “Mo Ibrahim's Index of African Governance," 2010: http://peacewomen.org/ sites/default/files/wps ibrahimindexreport moibrahim october2011 0.pdf 
Onis, Ziya, "Review: The Logic of the Developmental State." Comparative Politics, Vol. 24, Issue 1, 1991

Pritish Behuria, "The Tentative Developmental State in Rwanda: From Anti-Manufacturing to Recapturing the Domestic Market," LSE Blogs, 2016: https://blogs.lse.ac.uk/internationaldevelopment/2016/09/30/the-tentative-developmental-state-in-rwanda-from-anti-manufacturing-torecapturing-the-domestic-market/

Rodgers, Alisdair, Noel Castree and Rob Kitchin, "A Dictionary of Human Geography: Developmental State," Oxford Reference, 2013: https://www.oxfordreference.com/view/10.1093/ acref/9780199599868.001.0001/acref-9780199599868-e-391

Sawani, Youssef Mohammad, "Gaddafi's Legacy, Institutional Development, and National Reconciliation in Libya," Contemporary Arab Affairs, Vol. 13, Issue 1, 2020.

Sen, Armatya, Development as Freedom, New York: Anchor Books, 1991.

Takeuchi, Shinichi "Development and Developmentalism in Post-genocide Rwanda," in Takagi Y., Kanchoochat V. and Sonobe T. (eds.) Developmental State Building. Emerging-Economy State and International Policy Studies, Springer: Singapore, 2019.

UN Economic and Social Commission for Western Asia, "Developmental State Model," 9 November 2017: https://www.unescwa.org/developmental-state-model

United National Development Plan, "Human Development Indices and Indicators: 2018 Statistical Update, Ethiopia,, 2020: http://hdr.undp.org/sites/default/files/Country-Profiles/ETH.pdf

United Nations Meetings Coverage and Press Releases, "Secretary-General Welcomes Libyan Political Dialogue Forum's Selection of Temporary Executive Authority, Calls upon All Parties to Respect Tunis Road Map," 5 February 2021: https://www.un.org/press/en/2021/sgsm20572.doc.htm

Walsh, Declan and Latif Abdi Dahir,"Why is Ethiopia at war with itself?" The New York Times, 5 November 2020: https://www.nytimes.com/2020/11/05/world/africa/ethiopia-tigray-conflict-explained.html

Walsh, Declan. "A Radical Idea to Rebuild a Shattered Libya: Restore the Monarchy," The New York Times, 25 May 2016: https://www.nytimes.com/2016/02/25/world/middleeast/a-radical-idea-to-rebuild-a-shattered-libya-restore-the-monarchy.html

Wehrey, Frederic, "This War is Out of Your Hands," Centre on the Future of War, 14 September 2021: https://www.newamerica.org/international-security/reports/this-war-is-out-of-our-hands/

Weis, Toni, "Ethiopia's Vanguard Capitalists: How the EPRDF Mobilizes for Economic Development," Foreign Affairs, 26 May 2016: https://www.foreignaffairs.com/articles/ethiopia/2016-05-26/ ethiopias-vanguard-capitalists

Weis, Toni. "Vanguard capitalism: party, state, and market in the EPRDF's Ethiopia." Doctoral Thesis: University of Oxford, 2015.

World Bank Group, "Libya Economic Monitor," 14 August 2020: https://www.worldbank.org/en/region/mena/publication/libya-economic-monitor

World Bank Group, “Africa's Future and the World Bank's Support to it,” March 2011: https://documents. worldbank.org/en/publication/documents-reports/documentdetail/393441468202137255/africas-future-and-the-world-banks-support-to-it-africa-regional-strategy 
World Bank Group, “Ethiopia Country Profile,” 2019: https://data.worldbank.org/country/ethiopia

World Bank Group, “Ethiopia's Great Run: The Growth Acceleration and How to Pace It”, 2016: http:// documents1.worldbank.org/curated/en/693561467988949839/pdf/99399-REVISED-PUBLICthiopia-Economic-Update-2-11-16-web.pdf

World Bank Group, “Population Percentage below Age 14 in Ethiopia,, 2020: https://data.worldbank. org/indicator/SP.POP.0014.TO.ZS?locations=ET

Zakaria, Fareed, The Future of Freedom: Illiberal Democracy at Home and Abroad, W. W. Norton and Company: New York, 2003. 


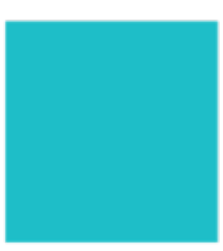

Research Project Report May 2021

2021/06
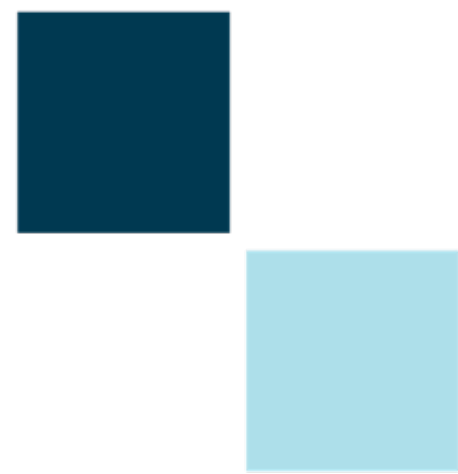

ISBN:978-92-9466-010-7

doi:10.2870/749290

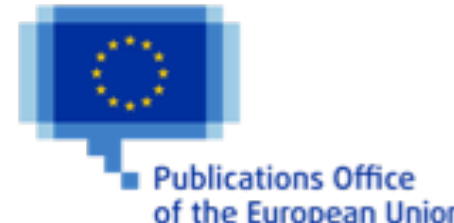

